\title{
TEACHING TRANSLATION FROM ENGLISH INTO ITALIAN AS a Purposeful activity in the language Classroom: AN EMPIRICAL STUDY
}

\author{
Maria Cristina Seccia ${ }^{1}$
}

\section{INTRODUCTION}

While the mutual relationship between language and translation pedagogy has been explored with reference to different language pairs, research on the benefits of pedagogical translation in the Italian language classroom is still scarce. In the anglophone context, some scholars have pointed out the benefits of teaching translation from Italian into the students' English Language 1 (L1) (see, for example, Laviosa, 2014; Panzarella, Walls, 2016; Panzarella, Sinibaldi, 2018). Moreover, two handbooks in particular (Hervey et al., 2000, 2005; Craige et al., 2000, 2016) propose ways of teaching and approaching translation from Italian into English in the Italian language classroom. To date, however, very few studies (see in particular Leonardi, 2010) have discussed pedagogical translation into Italian, which is usually perceived as more challenging by students.

«Pedagogical translation» here means a set of «translating activities and/or tasks that are included in foreign language teaching and learning», as defined by Lucía Pintado Gutiérrez (2018: 16). As she explains, these tasks enhance the development of specific language and translation skills and are based on various aspects of translation central to the language classroom, including pragmatic issues, language awareness, accuracy, intercultural competence, creativity, problem solving, autonomy and collaboration (ibidem: 16). Echoing the call for an interdisciplinary approach to translation teaching issued by the authors of an EU Directorate-General for Translation project (Pym et al., 2013: 125), Pintado Gutiérrez suggests that approaching translation teaching from both language pedagogy and translation studies perspectives is useful to further clarify among other issues - which activities pedagogical translation can entail (2019: 25-26). More specifically, she recommends discussing translation in the language classroom within the Common European Framework of Reference (CEFR) in light of the beneficial impact that this has had on language teaching and policy $(2018,25-26)$. Although much progress has been made in integrating translation in language pedagogy, as confirmed by some recently published studies (see Laviosa, González-Davies, 2020; Carreres et al., 2021), Pintado Gutiérrez's observation about the scarcity of specific research on particular practices of translation in language learning $(2018,13)$ still seems to be relevant. In light of this, this article aims to contribute to the current debate by discussing how teaching translation into Italian through a translation studies teaching approach (Nord, 1997a, 2018; Malmkjær, 1998) can enhance the students' language communicative competences. My discussion will be based on the students' reflections collected during six one-hour translation into Italian workshops addressed to final-year

\footnotetext{
${ }^{1}$ Università degli Studi di Udine; University of Hull.
} 
Modern Languages students at the University of Hull (UK), which I will examine through the lens of the CEFR relevant descriptors.

\section{Teaching Translation in the Language Classroom: An Overview}

Translation and language teaching have become increasingly interrelated since the CEFR Companion Volume (Council of Europe, 2018, 2020) legitimized translation in language pedagogy as a cross-linguistic mediation activity that enhances learners' ability to mediate between speakers belonging to different cultures in real-life situations, thus honing their plurilingual and pluricultural competences ${ }^{2}$. When mediating, learners create bridges by constructing and transferring meaning through interaction (2020: 90; see also 2018: 103). The co-construction of meaning is at the centre of the learning and teaching process (2020: 29; see also 2018: 27). From this perspective, learners are seen as language users and «social agents» who are enabled to act purposefully in real-life situations through translation and other communicative language activities $(2020: 28,29$, 32; see also 2018: 26, 27, 30). These consist of purposeful, collaborative tasks in the classroom whose primary focus is not language but the task outcomes (2020: 29, 30, 31; see also 2018: 27, 28, 29). Within this framework, language is therefore seen as a «vehicle for communication» (2020: 29; see also 2018: 27) and translation as one of several communicative language activities building on and enhancing learners' plurilingual and pluricultural competences which, in turn, enable them to communicate successfully.

Within the context of this communicative framework, Ángeles Carreres and María Noriega-Sánchez offer a valuable task-based approach resonating with the actionoriented approach described in the CEFR which suggests how translation can be effectively used in the language classroom (2011: 282, 285; see also Carreres, 2006: 17). More specifically, Carreres and Noriega-Sánchez propose a task-based approach consisting of well-thought-through and realistic activities resembling real-life professional translation commissions. Based on their teaching experience of translation into Spanish as L2, they argue that this approach helps students to combine effective communication with accurate language use and fosters interaction and collaboration (2011: 287-289). Whilst translation into L2 in the language classroom has long been criticized as unrealistic, counterproductive and demotivating (see Marsh, 1987: 24-25; Irons, 1998: 29 in Schjoldager, 2004: 133; Coleman, 1986: 101-102), Carreres and Noriega-Sánchez (2011: 282, 285) highlight that translating in this language direction can rather be stimulating, productive and perceived as meaningful by students if taught as a real-life activity as is usually done on translator training programs, where translation is seen as a professional product (see also Carreres, 2006: 17). Following a number of empirical studies (see Kobayashi, Rinnert, 1992; Uzawa, 1996; Källvist, 1998, 2004, 2008; Cohen, Brooks-Carson, 2001; Schjoldager, 2004; Vaezi, Mirzaei, 2007; Laufer, Girsai, 2008; Whyatt, 2009; Sánchez Cuadrado, 2011 in Pintado Gutiérrez, 2018: 13) which had already demonstrated that translation into L2 enhances the students' language proficiency (with specific reference to traditional language skills such as writing, vocabulary control and grammatical accuracy), Carreres and Noriega-Sánchez crucially helped the theoretical debate to shift its focus from whether pedagogical

\footnotetext{
2 The CEFR Companion Volume published in 2020 was first made available online in 2018 as the CEFR Companion Volume with New Descriptors. This volume is to be followed by Enriching 21st Century Language Education: The CEFR Companion Volume, Examples from Practice (North et al., 2021) (still in press at the time of writing) offering proposals that include hands-on mediation lessons and tasks (Carreres et al., 2021: 4).
} 
translation into L2 can be used effectively in the language classroom to how this can be done.

In proposing task-based activities resembling real-life professional translation commissions, the scholars contributed to the ongoing dialogue between language pedagogy and translator training whose strong relationship has been highlighted by a number of scholars (see Haywood et al., 1995, 2009: 2; Delisle, 1980; Lavault, 1985: 108; Keith, Mason, 1987: v-vi; Sewell, Higgins, 1996; Malmkjær, 1998). Carreres shows that both translating in real life and learning a language are inextricably linked to a communicative purpose (2014: 125; see also 2006: np), as demonstrated by the fact that both professional translation competence and the plurilingual and pluricultural abilities expected from language graduates are grounded in communication. A number of scholars now work at the intersection of language pedagogy and translator training (see González-Davies, 2004, 2014, 2018; Carreres, Noriega-Sanchez, 2011; Pintado Gutiérrez, 2012, 2018, 2019; Laviosa, 2014; Carreres, Noriega-Sánchez, Calduch, 2018; Pym, 2018; Enriquez Raido, Austermuhl, Sanchez Torron, 2020), thus bridging the gap between these two disciplines. There is, however, still some divergence, as suggested for instance by the CEFR authors' clarification that its translation descriptor scale (with no focus on the language direction) is not intended to relate to the activities of professional translators or to their training (Council of Europe 2020: 102; see also 2018: 113).

It is against this background, then, that in the next section I will show that in reality the idea of translation illustrated in the CEFR resonates with the notion of translation as discussed in translator training. This will be confirmed by my analysis of the ways in which Christiane Nord's (1997/2018) and Kirsten Malmkjær's (1998) translation teaching models can help students to enhance their Italian language communicative competences.

\section{TRANSLATION INTO ITALIAN AS A PURPOSEFUl ACTIVITY IN THE LANGUAGE CLASSROOM: A THEORETICAL FRAMEWORK}

The CEFR's idea of translation as an activity with communication as its final aim resonates in particular with the notion of translation as discussed by functionalist translation studies scholar Nord, among others, who sees professional translation as a form of action involving linguistic and socio-cultural factors which aims to fulfill communicative purposes. As we shall see, Nord designed a teaching model for translator trainees which is grounded in her idea of professional translation. It is precisely the notion of «purpose» that steers both the CEFR's idea of translation activity (and, more generally, its action-oriented language teaching and learning approach) and Nord's idea of target-text oriented translation. The concept of «purpose» is crucial in Nord's view of translation as confirmed by her definition of translation as a "purposeful activity» (1997a/2018): translators, as agents, transfer a text from the source language and culture to the target language and culture depending on the target-text's implied function and prospective context (hence, the definition «target-text oriented translation»). Similarly, when performing the mediation activities proposed by the CEFR, language learners act as social agents creating bridges and helping to construct or convey meaning depending on the goal of their communicative action. Both language learners and translators are therefore encouraged to focus on the purpose, namely on the aim of their communicative action, whether it be co-constructing meaning through translation (or other mediation activities) in the language classroom, or translating a text in a professional context. Just as language learners are encouraged to use language by focusing on the goal of their communication, as determined by the real-life 
communicative situation simulated in the classroom, translators make translation choices depending on the function of their translation (determined by its implied audience), as outlined in their translation brief. This document indicates the main details of the commission, including the target-text receivers; reason; medium; time and place of reception; and any special conditions under which the translation (target text) should fulfill its intended function. In Nord's terms, the function of a text can be «referential» (if the main purpose is to convey information); «appellative» (if the target text is mainly aimed at persuading readers); «expressive» (if the main purpose is to evoke emotion); and «phatic» (if the main aim is to establish, maintain or end contact with the receiver) (1997a/2018: 9-43).

In the translation teaching model (1988/2005: 155-190; 1994; 1997a/2018: 38-73) designed by Nord for translator trainees and based on her «top-down» model for translation-oriented text analysis (1988/2005: 5-154), Nord recommends that translator trainers encourage their students to envisage the context in which their translation might be realistically received, thus creating a prospective target-text profile similar to a translation brief that they would receive in a professional context. This helps translator trainees to focus on the function(s) of their target text (hence, the definition «translation-oriented model»). Depending on the target-text function(s), translator trainees are encouraged to use specific translation strategies (ibidem: 58). Translator trainees should bear the examination of their translation brief in mind when analyzing their original text (source text) from the pragmatic macro-level to the linguistic microlevel (hence the expression «top-down model»). This enables them to identify any «translation problems» by which Nord means any objective translational difficulties that are inherent in the translation task (ibidem: 59), and to find solutions accordingly. In order to facilitate this process, Nord identifies four categories of «translation problem»: 1) «pragmatic translation problems», which are posed by any discrepancies between the source and target communicative situations, as might happen, for example, if the function of the target text is different from that of the source text;

2) «cultural translation problems», which arise from any shifts in register, from the presence of any culture-bound terms, and from any differences in terms of text-genre conventions, namely «the result of the standardization of communication practices» (ibidem: 61-62; see also 1997b: 59-61);

3) «linguistic translation problems», which are posed, for instance, by terminology, grammar and syntax;

4) any «specific translation problems», which are specific to the text with characteristics that cannot easily be transferred to other translation tasks (1997a/2018: 60). The order in which these «translation problems» are categorized confirms Nord's «top-down» procedure: after analyzing the source text against its translation brief, translator trainees should solve any translation problems by starting from the pragmatic macrostructure, moving to the cultural level and down to the linguistic micro-level. In this way, translator trainees will be able to evaluate whether the relevant functional units (such as the textual function, any culture-bound terms, and the register) can be kept unaltered or should be adjusted in order to meet the client's requirements outlined in the translation brief (ibidem: 60). Any alterations might be due, for instance, to a discrepancy between the source and target-text readers' cultural knowledge, the genre stylistic conventions, or the media through which the source and the target text are received. Facilitating the translator trainees' identification process of potential translation problems and solutions helps them to avoid any «translation errors» by which Nord means «a failure to carry out the instructions implied in the brief and an inadequate solution to a translation problem» (ibidem: 69). 
Nord's functionalist translation-training approach implicitly underpins the model put forward by Malmkjær (1998: 7-8) with the aim of presenting translation (not necessarily into L2) to Modern Languages students as a realistic and fruitful activity. More specifically, Malmkjær suggests engaging students in five stages typically undertaken by professional translators:

1) «anticipation», during which they discuss the source-text context and a potential context for their translation;

2) «resource exploitation», that is, learners gather terminology and research tools necessary to translate a text;

3) «co-operation», where students discuss potential challenges and their solutions;

4) the act of «translation» itself;

5) «revision», namely, editing the translation (ibidem: 7).

Malmkjær argues that by encouraging learners to undertake these five stages, translation proves to be a realistic and fruitful activity inclusive of and enhancing all the four traditional language skills. Moreover, she suggests that properly situating a translation in this way helps students to realize that a one-to-one linguistic correspondence is not necessarily achievable or desirable and it encourages them to think in both languages (ibidem: 8).

Although operating in different teaching and learning contexts, both Nord and Malmkjær suggest designing properly-situated, real-life translation tasks, that is, properly briefed functional translation assignments undertaken for a clearly stated purpose. As pointed out by Nord, the clearer the idea students have of the situation in which they are translating, the more confident they feel in diverging from the syntactical structures and the vocabulary used in the source text, if necessary, thus avoiding interference from their L1 (1997a/2018: 63, 69; see also Malmkjær, 1998: 8; Leonardi, 2010: 20; Carreres, Noriega-Sánchez, 2011: 287).

While Nord's «top-down» approach has been used - although not always explicitly to design teaching models (see Vienne, 1994; Wetherby, 1998; Seel, 2015), to design translation into L1 classes delivered to undergraduate students (see Brusasco et al., 2011) and implemented by Britta Nord (2015) to carry out an error-analysis of postgraduate students' translation assignments, surprisingly, to date, there are no studies discussing the uses of Malmkjær's model, which will be implemented in this study.

\section{RESEARCH AIMS, HYPOTHESES AND METHODOLOGY}

Although inevitably new challenges and practices surrounding the role of translation in language learning have emerged since Nord's and Malmkjær's teaching models were created, I will nonetheless demonstrate how their focus on the communication purpose makes them valuable tools in designing purposeful, collaborative, real-life tasks, thus enhancing the learner's ability to communicate in real life. I will show that focusing on their communication purpose leads students to enhance three language communicative competences in particular: sociolinguistic and pragmatic competences, which are closely interrelated, and pluricultural competence. Pluricultural competence, which refers to the ability to use languages and interact with people of different cultures (Council of Europe, 2020: 123; see also 2018: 159; 2001: 168), builds on and further develops pragmatic and sociolinguistic competences in particular. Pragmatic competence is concerned «with actual language use in the (co)construction of text» and is shown, among other things, in the learner's ability to transfer a message by successfully conveying its communicative function (2020: 137; see also 2018: 138; 2001: 125). Similarly, sociolinguistic competence is concerned with the «knowledge and skills 
required to deal with the social dimension of language use» and is reflected, for instance, in the ability to conform to politeness norms and to use linguistic markers of social relations as well as appropriate register and idiomatic expressions (2020: 136; see also 2018: 137; 2001: 118). These competences are crucial in the formation of language graduates as future cultural mediators. While cultural mediation requires knowledge of cultural and text-genre conventions, social mediation requires - among other skills awareness of cultural perspectives and expectations (North, Piccardo, 2016: 13, 14).

The aim of this study is based on the hypothesis that teaching translation into Italian as a purposeful activity that simulates real-life translation commissions and encourages students to focus on the communicative purpose that their translation is expected to fulfill, helps them to use Italian language purposefully when mediating a text, thus enhancing their communicative ability in real life depending on the situation, their interlocutors' cultural background and the kind of relationship they have with them. This aim will be achieved through a qualitative analysis of the students' reflections shared in the in-class discussions during six one-hour translation into Italian workshops that I delivered to fifteen undergraduate final-year students taking Italian as part of their degree in Modern Languages at the University of Hull. In focusing on the in-class discussions, I will consider translation as a process, thus adding a new perspective to the results of the existing empirical studies mentioned in Section 1, which mainly consist of quantitative analyses of students' translation assignments into L2 aimed at evaluating translation (discussed as a product) as a method of assessing traditional language skills.

The translation into Italian workshops mentioned above were delivered within the ECTS 10-credit final-year Italian language undergraduate module Italian Language: Advanced Language Skills in Semester 1 of the academic year 2019/2020. This language module, which was the first offering classes entirely devoted to translation into Italian, included twelve one-hour sessions of translation in alternate weeks from and into Italian in addition to writing, grammar, conversation and interpreting classes. Before starting this module, most of the fifteen students had a CEFR level B2 and, as final-year students, were expected to reach level C1 by the end of the academic year. Only one student started the four-year degree course as a non-beginner in Italian. All students had been studying at least one other language as part of their degree in Modern Languages. They all had English as their first language with the exception of two students who had more than one L1. Finally, they had all spent one semester as exchange students in an Italian partner university in the previous academic year.

The constraints faced within this teaching context, such as a relatively limited number of contact hours and the students' lack of previous experience of translation into Italian, coupled with the expectation of their achieving a professional-level language proficiency by the end of the academic year, played a crucial role in deciding to combine Nord's and Malmkjær's models. More specifically, I structured my six workshops according to the five stages recommended by Malmkjær due to its close resemblance to real-life commissions, an aspect which I expected would stimulate the students. I then followed Nord's functional hierarchy of translation problems to design well-thoughtthrough translation activities, guiding students closely through the five stages recommended by Malmkjær.

Overall, within my six workshops, students completed the translation of each of their three texts (a patient information leaflet, a user guide and a tourist flyer) by the end of every other session, thus working on the same text over two workshops (henceforth Workshops A and Workshops B). For each of the three source texts, I simulated a reallife professional commission by playing the role of a translation project manager of a local translation agency and giving a translation brief to the students, who acted as inhouse translators. I filled in an authentic translation brief template (available on the 
London-based translation agency TranslateMedia's website), thus presenting the students with the main details of the translations commissioned by their clients ${ }^{3}$. In Workshops A, students undertook Malmkjær's first two translation stages: anticipation and resource exploitation. These prepared students for Malmkjær's third stage - the translation itself - which they completed as homework and emailed to me at least nine working days before Workshops B. Any comments anticipated in the students' written responses, together with any others shared directly in class in the following workshop, were the starting point for Workshops B and the brain-storming in-class discussion - Malmkjær's co-operation stage - which in turn informed the next and last in-class discussion. This consisted of Malmkjær's revision stage during which students edited a selection of anonymized translated passages extrapolated from their translations. At the end of Workshops B, students received written feedback on their full translation, which enabled them to monitor their progress more closely despite the relatively limited class contact time.

All three source texts were authentic special-purpose texts or «pragmatic texts,» in Jean Vienne's terms (1994: 52), namely texts written with a specific purpose and for a specific type of reader. This selection was intended to help students to identify any important details in the translation commission more easily, thus enhancing their pragmatic competence. Moreover, considering that in a real-life context these texts are more likely to be translated into the translator's L2, I expected them to help me to present the translation activities in a realistic, meaningful and thus stimulating way. I divided my workshops by text genre in order to help students to: identify languagespecific patterns in structural organization and syntactic features; familiarize themselves with genre stylistic conventions; reflect on how these - as they are closely linked to culture - vary across languages, thus enhancing the students' pluricultural competence. In selecting the text genres, I considered Nord's recommendation to start with highly conventionalized texts with clear functions for which parallel texts can be found in the target language (Nord, 1994: 66). As I was expecting, moving from the translation of highly standardized texts, such as patient information leaflets and user guides, to tourist flyers, gave me the opportunity to challenge the students' preconception that lexical equivalence is always achievable and desirable and to let them reflect on the importance of achieving functional equivalence when translating texts with a strong appellative function, which relies on the target-text readers' knowledge and cultural expectations.

All teaching material was made available in advance on the University VLE to enable students to read the relevant source text and translation brief and to prepare Workshops A-Activities 1-3 and both Workshops B Activities at home in their own time. These were then discussed in class where we also completed Workshops A-Activities 4-6.

In this article, I will focus on the activities proposed and the students' reflections collected in the final two Workshops A and B centered on the translation of a tourist flyer. This choice is informed by the predominant appellative function conveyed by this text genre, together with the high presence of culture-bound terms and «emotional» and «creative» language devices (Torresi, 2010) characterizing it, thus offering opportunities for students to enhance their pragmatic, sociolinguistic and pluricultural competences, as discussed below. The tourist-flyer translation Workshop A and Workshop B were designed to help students to translate the source text Lake District Getaway taken from an online tourist guide of British holiday destinations available on Avanti Destinations. ${ }^{4}$ This

\footnotetext{
${ }^{3}$ https://www.translatemedia.com/wp-content/themes/translatemedia/media/creative-translationbrief.pdf.

${ }^{4}$ https://www.avantidestinations.com/landing/flyers/2019-Avanti-VisitBritain-Phase2-Flyer02062019.pdf.
} 
specific text was chosen due to the number of translation challenges posed by the presence of idiomatic expressions, informal register, creative and emotional language devices and culture-bound terms, which were expected to enhance in particular the students' pragmatic, sociolinguistic and pluricultural competences.

\section{RESULTS: TEACHING AND LEARNING ACTIVITIES AND IN-CLASS DISCUSSIONS}

\subsection{Workhop A: Anticipation and resource exploitation stages}

Like the previous two source texts, tourist flyer Lake District Getaway was provided to students together with a translation brief (Figure 1), which helped students to undergo Malmkjær's first translation stage (anticipation).

Figure 1. Workshop $A$ and Workshop B translation brief

\begin{tabular}{|l|}
\hline Job Name \\
Avanti Destinations tour guide \\
into Italian
\end{tabular}

$$
\begin{aligned}
& \text { Your Job Reference } \\
& \text { WorkshopsA+B_Text3_Tourist }
\end{aligned}
$$

\section{Brand/Product/Company}

Tour operator Avanti Destinations is localizing their website in different languages and has commissioned us to translate their online tour guide into Italian.

\section{Where and how will the translated text be used?}

This flyer will be published on Avanti Destinations website by February 2020.

\section{What is the desired response from readers?}

Web visitors, who are likely to be already interested in British culture, should be persuaded to book the tours advertised.

\section{Who is the target audience?}

While Avanti Destinations would like to attract a wide audience, these tours are ideal for young couples.
Tone of voice/Image/Style of Address to the Reader

Readers should be addressed with a personal tone and an informal register. The language should be catchy and the guide should be quick to read.

\section{Reference/Context/Background Information/Resources}

Avanti Destinations have decided to localize their website in a number of languages as most tour operators and tourism organisations now have multilingual websites. Please see the Lignano Sabbadioro page published on the Friuli Venezia Giulia official tourism website as a useful example of the type of language, tone and register to use.

\section{The one thing to communicate}

The main aim is to inform web visitors of the main details of the tours advertised and to persuade them to book. 
The anticipation stage was facilitated through Activities 1-3 (Figure 2), which students had prepared in advance and which I had designed following Nord's top-down process, thus encouraging them to reflect on how to deal with any pragmatic translation problems determined by the target-text's implied function and prospective context.

Figure 2. Worksop $A$ activities 1-3 (anticipation stage)

\section{Esercizio 1: Discutiamo le indicazioni del/della cliente!}

Rispondi alle seguenti domande sulla base del translation brief che hai ricevuto.

a. Quale funzione avrà la tua traduzione?

$\square$ Referenziale

$\square$ Appellativa

$\square$ Espressiva

b. A chi sarà rivolta la traduzione?

c. Che tipo di registro e tono dovrai usare?

d. Cosa raccomanda in particolare il/la cliente?

\section{Esercizio 2: Analizziamo il testo di partenza!}

Rispondi alle seguenti domande sulla descrizione dei tour che hai letto a casa.

a. Qual è la funzione del testo?
$\square$ Referenziale
$\square$ Appellativa
$\square$ Espressiva

b. A chi è rivolto il testo?

c. Come sono il registro e il tono? Dài alcuni esempi.

\section{Esercizio 3: Individuiamo le problematiche traduttive!}

Rispondi alle seguenti domande mettendo una $X$ sotto $N o$ o Si a seconda se il tuo testo di partenza presenta le problematiche traduttive elencate nella tabella. Se pensi di sì, dài maggiori informazioni, possibilmente con un esempio tratto dal testo.

\begin{tabular}{|c|l|l|l|l|}
\hline & \multicolumn{1}{|c|}{ Eventuali problematiche } & No & Sì & $\begin{array}{l}\text { Eventuali dettagli e/o } \\
\text { esempi tratti dal testo }\end{array}$ \\
\hline $\mathbf{a}$ & $\begin{array}{l}\text { La traduzione avrà una funzione diversa da } \\
\text { quella del testo di partenza? }\end{array}$ & & & \\
\hline $\mathbf{b}$ & $\begin{array}{l}\text { La traduzione sarà rivolta a un tipo di lettori } \\
\text { e lettrici diverso rispetto a quello del testo } \\
\text { di partenza? }\end{array}$ & & & \\
\hline
\end{tabular}




\begin{tabular}{|l|l|l|l|l|}
\hline $\mathbf{c}$ & $\begin{array}{l}\text { Ci sono elementi culturali britannici nel } \\
\text { testo di partenza? }\end{array}$ & & & \\
\hline $\mathbf{d}$ & $\begin{array}{l}\text { Quando tradurrai il testo, dovrai rispettare } \\
\text { delle convenzioni stilistiche? }\end{array}$ & & & \\
\hline $\mathbf{e}$ & $\begin{array}{l}\text { Dovrai usare un registro e un tono diversi } \\
\text { rispetto a quelli usati nel testo di partenza? }\end{array}$ & & & \\
\hline $\mathbf{f}$ & $\begin{array}{l}\text { Nel testo di partenza ci sono termini legati } \\
\text { al settore turistico che non conosci? }\end{array}$ & & & \\
\hline $\mathbf{g}$ & $\begin{array}{l}\text { Nel testo di partenza ci sono delle frasi con } \\
\text { una struttura che creerà difficoltà da un } \\
\text { punto di vista grammaticale e/o sintattico? }\end{array}$ & & & \\
\hline
\end{tabular}

Following Nord's recommendation, we started by analyzing the translation brief through Activity 1, consisting of four questions about the main client's requirements. Reflections about the textual function, readers and register, with reference this time to their source text, were then shared when undertaking Activity 2, thus following Nord's recommendation of analyzing the source text against its translation brief. The students' reflections on their translation brief and source text were brought together when addressing the YES/NO questions included in the brainstorming Activity 3, which led them to explicitly compare the source and target text communicative situations and therefore to anticipate any resulting potential translation problems, as recommended by Nord. The questions were designed by following the scholar's top-down procedure. Addressing Questions $a-b$, which were meant to identify any pragmatic translation problems, led students to note that the communicative situations in both the prospective translation and the source text were the same, as both texts were meant to simultaneously convey a referential and appellative function and were addressed to a young audience. This led students to conclude that they would not encounter any pragmatic translation problems. On the other hand, they identified a discrepancy between the source and target-text readers' interest in, and familiarity with, British culture, following their assumption that the English-language source text was likely to be addressed mainly to home tourists. Anticipating this translation challenge revealed the students' awareness of their own role as mediators between British culture and their Italian readers. Moreover, students anticipated a translation challenge posed by nonstandard expressions such as examples of informal language (e.g. getaway), emotional language devices (e.g. calm waters; peaceful day while you and your loved one share a bottle of prosecco under blue, sunny skies) and creative language devices (e.g. scenic escape). The students' concern with the challenge posed by retaining an informal register suggested their language sensitivity. This was confirmed when anticipating that they would address their Italian readers by the informal second person singular pronoun $t u$. In light of the informal register requested in the translation brief, students expected this pronoun to help them establish a direct relationship with their readers, thus successfully conveying the appellative function of the text. These observations suggested that focusing on the purpose of their act of communication (to attract readers' attention and persuade them to book the advertised tour) strengthened their ability to «adapt their register to the audience concerned», which is in line with the CEFR C1 sociolinguistic competence descriptor (Council of Europe, 2020: 154; see also 2018: 156). Overall, the first three activities, which encouraged students to reflect on the language to use at a pragmatic level in light of the appellative function expected from their prospective translation, helped them to enhance their «functional competence,» which «includes flexibility in the 
use of one's repertoire and the selection of appropriate sociolinguistic choices» (2020: 138; see also 2018: 139).

Since this was the students' first time dealing with register, the next three in-class activities focused on this aspect and on culture-bound terms (Activities 4-6) (Figure 3).

Figure 3. Workshop A Activities 4-6 (resource exploitation stage)

\section{Esercizio 4: Vediamo come affrontare le problematiche legate al registro!}

Guarda il video sul Galles dal minuto 8:00 al minuto 8:31. Scrivi le espressioni informali dette dal travel blogger in corrispondenza delle espressioni standard indicate nella tabella in basso e poi traducile in inglese usando lo stesso registro.

\begin{tabular}{|c|c|c|c|}
\hline & $\begin{array}{l}\text { Espressioni in un registro } \\
\text { standard }\end{array}$ & $\begin{array}{l}\text { Espressioni } \\
\text { equivalenti usate dal } \\
\text { travel blogger in un } \\
\text { registro informale }\end{array}$ & $\begin{array}{l}\text { Traduzione in } \\
\text { inglese in un registro } \\
\text { informale }\end{array}$ \\
\hline a & $\begin{array}{l}\text { Siamo pronti per iniziare una nuova } \\
\text { giornata in direzione di Anglesey. }\end{array}$ & & \\
\hline b & $\begin{array}{l}\text { Andiamo a bere velocemente un } \\
\text { caffè! }\end{array}$ & & \\
\hline c & Altro che un caffè veloce! & & \\
\hline d & E ora andiamo ad Anglesey! & & \\
\hline
\end{tabular}

\section{Esercizio 5: Vediamo come affrontare gli elementi culturalmente specifici!}

a. Secondo te perché il travel blogger nel video sul Galles ha detto bacon invece di pancetta? Tu tradurresti bacon? Perché?

b. Questa è una citazione (che ti era stato chiesto di leggere a casa) di Mirella Agorni tratta dal libro Prospettive linguistiche e traduttologiche negli studi sul turismo.

'L'efficacia pragmatica è alla base di tutti i testi che presentano una funzione persuasiva, e abbiamo già sottolineato come il linguaggio turistico presenti una commistione di funzioni promozionali e informative. La traduzione degli elementi cosiddetti culturalmente specifici presenta infatti il duplice scopo di catturare l'attenzione del turista e offrire un saggio di ciò che potrà sperimentare di persona. La traduzione turistica si pone infatti l'arduo compito di conciliare strategie di traduzione funzionali pur mantenendo il sapore di autenticità che caratterizza la diversità culturale che si vuole far conoscere. Un certo grado di distanza culturale infatti è una caratteristica costitutiva del linguaggio del turismo, e come tale deve essere conservato e trasmesso, in maniera fruibile, al potenziale turista' (Agorni, 2012: 13).

c. Tenendo in considerazione l'osservazione di Agorni, cosa farai quando tradurrai l'elemento culturalmente specifico Cumberland Rum Butter presente nel tuo testo di partenza?

Spiegherò cos'è per dare ai lettori e alle lettrici un'idea di cosa potranno assaggiare esattamente.

$\square$ Lo lascerò in inglese per incuriosire i lettori e le lettrici e per mantenere l'autenticità della cultura britannica.

Altro (spiega cosa farai e perché): 


\section{Esercizio 6: Iniziamo a tradurre!}

Nella prima tabella in basso sono elencate delle strategie che possono essere usate per tradurre elementi culturalmente specifici e sono accompagnate dalla definizione e un esempio. Il primo esempio è tratto dalla traduzione di VisitScotland della frase Haggis is Scotland's national dish and the crowning glory of a traditional Burns Supper. Gli altri esempi, invece, sono traduzioni alternative della stessa frase, aggiunte per illustrare le altre strategie traduttive.

Dopo aver letto la definizione di tutte le strategie con il relativo esempio, traduci la frase 'Enjoy their prized gingerbread, Cumberland Rum Butter and other local treats,' tratta dal tuo testo di partenza, applicando le due strategie che ti sono state assegnate per l'elemento culturalmente specifico.

Tenendo in considerazione sia l'osservazione di Agorni (esercizio 5) che la funzione della tua traduzione e il tipo di lettori e lettrici a cui sarà rivolta (come indicato nel translation brief di Avanti Destinations), preparati a discutere con il resto della classe se la tua versione è adatta in questo contesto spiegandone il motivo.

\begin{tabular}{|c|c|c|c|}
\hline & $\begin{array}{l}\text { Strategie traduttive } \\
\text { (versione originale: } \\
\text { Leppihalme 2011: } 126 \text { - } \\
\text { 130) }\end{array}$ & Spiegazione & Esempi \\
\hline 1 & Prestito & Lo lascerai in inglese & $\begin{array}{l}\text { L'haggis è il piatto nazionale della Scozia e } \\
\text { il pezzo forte di una Burns supper tradizionale. }\end{array}$ \\
\hline 2 & Esplicitazione & Spiegherai che cos’è & $\begin{array}{l}\text { L'haggis è il piatto nazionale della Scozia e } \\
\text { il pezzo forte di una serata in cui si } \\
\text { festeggia la nascita del poeta scozzese } \\
\text { Robert Burns. }\end{array}$ \\
\hline 3 & $\begin{array}{l}\text { Prestito ed } \\
\text { esplicitazione }\end{array}$ & $\begin{array}{l}\text { Lo lascerai in inglese } \\
\text { e spiegherai che cos'è }\end{array}$ & $\begin{array}{l}\text { L'haggis è il piatto nazionale della Scozia e } \\
\text { il pezzo forte della Burns supper, ovvero una } \\
\text { serata in cui si festeggia la nascita del } \\
\text { poeta scozzese Robert Burns. }\end{array}$ \\
\hline 4 & Calco & $\begin{array}{l}\text { Lo tradurrai } \\
\text { letteralmente anche se } \\
\text { non esiste in italiano }\end{array}$ & $\begin{array}{l}\text { L'haggis è il piatto nazionale della Scozia e } \\
\text { il pezzo forte della "Cena di Burns.» }\end{array}$ \\
\hline 5 & Calco ed esplicitazione & $\begin{array}{l}\text { Lo tradurrai } \\
\text { letteralmente (anche } \\
\text { se non esiste in } \\
\text { italiano) e spiegherai } \\
\text { che cos'è }\end{array}$ & $\begin{array}{l}\text { L'haggis è il piatto nazionale della Scozia e } \\
\text { il pezzo forte della cosiddetta "Cena di } \\
\text { Burns," ovvero una serata in cui si } \\
\text { festeggia la nascita del poeta scozzese } \\
\text { Robert Burns. }\end{array}$ \\
\hline 6 & Adattamento culturale & $\begin{array}{l}\text { Lo tradurrai o } \\
\text { spiegherai con un } \\
\text { termine simile (ma } \\
\text { che non corrisponde } \\
\text { allo stesso elemento } \\
\text { culturale) che esiste } \\
\text { nella cultura italiana }\end{array}$ & $\begin{array}{l}\text { L'haggis è il piatto nazionale della Scozia e } \\
\text { il pezzo forte di una festa che corrisponde al } \\
\text { nostro Dantedi. }\end{array}$ \\
\hline 7 & Neutralizzazione & $\begin{array}{l}\text { Lo tradurrai usando } \\
\text { un termine più } \\
\text { generico che non è } \\
\text { specifico di nessuna } \\
\text { cultura }\end{array}$ & $\begin{array}{l}\text { L'haggis è il piatto nazionale della Scozia e } \\
\text { il pezzo forte di una festa. }\end{array}$ \\
\hline 8 & Omissione & Lo eliminerai & L'baggis è il piatto nazionale della Scozia. \\
\hline
\end{tabular}


(C) Italiano LinguaDue 2. 2021. M. C. Seccia, Teaching Translation from English into Italian as a Purposeful Activity in the Language Classroom: An Empirical Study

\begin{tabular}{|c|c|c|c|}
\hline & $\begin{array}{l}\text { Strategia } \\
\text { traduttiva } \\
\text { da usare }\end{array}$ & Traduzione & $\begin{array}{l}\text { Secondo te questa versione è adatta al } \\
\text { contesto? Perché? }\end{array}$ \\
\hline 1 & Prestito & & \\
\hline 2 & Esplicitazione & & \\
\hline 3 & $\begin{array}{l}\text { Prestito ed } \\
\text { esplicitazione }\end{array}$ & & \\
\hline 4 & Calco & & \\
\hline 5 & $\begin{array}{l}\text { Calco ed } \\
\text { esplicitazione }\end{array}$ & & \\
\hline 6 & $\begin{array}{l}\text { Adattamento } \\
\text { culturale }\end{array}$ & & \\
\hline 7 & Neutralizzazione & & \\
\hline 8 & Omissione & & \\
\hline
\end{tabular}

When completing Activity 4, for example, students were asked to identify the informal words spoken by a travel blogger in a video promoting the Welsh island of Anglesey and to translate them into English while keeping the same register ${ }^{5}$. While not all students recognized the colloquialism macché, they all understood its ironic tone. More generally, they all recognized the different effect created by the register shift in all the expressions listed in their activity, which they translated into informal English appropriately, such as in the case of let's go for a quick coffee (their proposed equivalent for andiamo a farci un caffettino) and and now off to Anglesey! (translating the original e poi via verso Anglesey.). In addition, the students observed that the travel blogger's catchy language, including colloquialisms and elliptical sentences, helped him to engage his audience. These are all examples of the students demonstrating sociolinguistic competence. Moreover, the students realized that by mentioning having coffee as the first activity of the morning, the travel blogger played on an Italian stereotype and that, by going for a typical English breakfast after saying macché caffettino, he presented his Italian audience with a British cultural stereotype. This revealed the students' pluricultural competence, as demonstrated by their ability to interpret cultural stereotypes belonging to both Italian and British communities in line with the CEFR relevant descriptor (2020: 125; see also 2018: 159).

The students' pluricultural competence was confirmed when completing Activities 5 and 6, which focused on culture-bound terms. The students' reflections on nonequivalence and on the resulting expected cultural translation problems posed by culture-bound terms such as Cumberland Rum Butter, suggested their awareness of the importance of acting as effective cultural mediators when translating creative and culture-embedded texts such as those aimed at tourists. The students acknowledged that it would be challenging to translate this culture-bound term clearly and concisely, as requested in the translation brief. In addressing Activity 5 multiple-choice Question $c$, the students explained that they would leave Cumberland Rum Butter in English, in order to preserve its authenticity and to retain the cultural difference, and that they would briefly explain it in order to make clear to readers what it is, thus encouraging them to try it. One student pointed out that since it would be challenging to describe this

\footnotetext{
${ }^{5}$ https://www.youtube.com/watch?v=1PRzGMYkDiM.
} 
delicacy concisely, one option would be to leave Cumberland Rum Butter in English and to add a picture. These observations revealed the students' pluricultural competence, namely their awareness of cultural difference and their ability to create a bridge between the two cultures, which is in line with the CEFR C1 relevant descriptor (2020: 125; see also 2018: 159). Overall, Workshop A activities, which can be seen as examples of «interaction activities,» also helped students to improve their fluency, which is part of the pragmatic competence, through evaluative spoken interaction that mainly took place in Italian.

Because of the limited amount of contact time, I further facilitated Malmkjær's second stage (resource exploitation) by providing students with an initial parallel text and encouraging them to collect some more texts in their own time in order to assimilate and familiarize themselves with the style conventionally used in Italian tourist literature. This parallel text (a Friuli Venezia Giulia official tourist office web page promoting Lignano Sabbiadoro, which is very popular with young people) was recommended in the translation brief as a reference point for stylistic preferences ${ }^{6}$. Moreover, I provided students with the Italian translation of a web page promoting the traditional Scottish meal haggis, published on the multilingual website of the Scotland National Tourist Organization VisitScotland, which students were encouraged to compare with its source text in their own time ${ }^{7}$. An excerpt from this source text and target-text pair was then included in Activity 6, which encouraged students to carry out a contrastive analysis and to consolidate their ability to put theory into practice.

\subsection{WORKSHOP B: CO-OPERATION AND REVISION STAGES}

Workshop A in-class activities and the students' consultation of parallel texts helped them to prepare the translation of their source text at home, thus proceeding through Malmkjær's third stage, namely the translation itself, which was then discussed and revised in Workshop B through Malmkjær's fourth and fifth translation stages (respectively co-operation and revision). This session's in-class activities mainly aimed to enhance the students' ability to verbalize any translation challenges faced and translation solutions adopted as well as to develop editing skills, which are all crucial competences in a professional context.

Activity 1 (Figure 4), which students had prepared at home and which facilitated the co-operation stage, consisted of three questions about translation problems posed by the source text (Question a); translation solutions adopted and the rationale behind them (Question b); and whether the translation problems faced and the solutions adopted matched those anticipated when discussing Workshop A-Activity 3 above (Question c). The students' concern with their figurative language expressions not «sound[ing] natural enough» in Italian shared in Workshop B-Activity 1 revealed their attempt to translate their text accurately and to avoid a literal approach to translation.

Figure 4. Workshop Activity 1 (co-operation stage)

\section{Esercizio 1: Discutiamo le problematiche che abbiamo affrontato!}

a. Dài un esempio di problematica che hai riscontrato in generale o riguardo a un aspetto in particolare:

${ }^{6}$ https://www.turismofvg.it/Lignano-

Sabbiadoro?UrlBack=aHR0cHM6Ly93d3cudHVyaXNtb2Z2Zy5pdC9BcmVlLXR1cmlzdGljaGU\%3D .

${ }^{7}$ https://www.visitscotland.com/it-it/see-do/food-drink/haggis/. 
b. Che soluzione hai trovato e perché?

c. Sono le stesse problematiche e soluzioni che avevi previsto quando abbiamo discusso il testo di partenza nella scorsa lezione?

Activity 2 (Figure 5) consisted of a collection of anonymized excerpts extrapolated from the students' translations which I had received by email and collated in a single document, depending on the types of translation problems that students had anticipated in Workshop A-Activity 3.

Figure 5. Workshop B Activity 2 (revision stage)

\section{Esercizio 2: Correggiamo la traduzione!}

In coppia correggi la frase che ti è stata assegnata a seconda delle indicazioni date nel translation brief e preparati a giustificare le tue correzioni nella discussione con il resto della classe.

1. Testo di partenza: A scenic escape into picturesque Cumbria is the best way to please both the eye and the palate.

Testo di arrivo: La bellezza naturale della pittoresca regione di Cumbria è il modo migliore per soddisfare sia l'occhio che il palato.

2. Testo di partenza: Grasmere Gingerbread Shop. Learn how writers and artists brought the first tourists to Grasmere and the deep connection this region shares with the local food. Enjoy their prized gingerbread, Cumberland Rum Butter and other local treats.

Testo di arrivo: Grasmere Gingerbread Shop (negozio). Impara come scrittori e artisti hanno portato i primi turisti a Grasmere e la connessione che questa regione ha con il cibo locale. Goditi il vero gingerbread, il Cumberland Rum Butter (un burro leggermente speziato a base di rum scuro) e altre prelibatezze locali.

3. Testo di partenza: Ullswater Steamer Cruise. A romantic experience on the calm waters of Lake Ullswater. Relax and spend this peaceful day while you and your loved one share a bottle of prosecco under blue, sunny skies.

Testo di arrivo: Crociera sul battello a vapore sull'Ullswater. Un'esperienza romantica sulle acque calme del lago Ullswater. Rilassatevi e trascorrete una giornata tranquilla mentre voi e la vostra persona amata condividete una bottiglia di prosecco sotto il cielo sereno e un bel sole.

4. Testo di partenza: Half Day Behind the Scenes Beatrix Potter Visit with Driver-Guide Half Day Lake District Farm Experience with Driver-Guide

3 Day Compact Manual Car Rental

Testo di arrivo: Visita di mezza giornata dietro le quinte di Beatrix Potter con autistaguida

Visita di mezza giornata per un'esperienza fantastica in una fattoria del Lake District con autista-guida

Noleggio per tre giorni di un'utilitaria con cambio a mano 
Students were divided into four groups, each of which was allocated a translated passage. They were asked to identify strengths and limitations in light of the requirements stated in the translation brief and to make revisions accordingly if some of these had not been met. Following Nord's top-down translation model, we started the plenary discussion by commenting on the pragmatic, cultural and linguistic problems posed by the translated passages. The last translated passage was selected in order to discuss the solution of some further linguistic translation problems that students had anticipated in Workshop A-Activity 3.

Both Student Group 2's positive feedback on the addition of negozio next to Grasmere Gingerbread Shop and one of their peers' suggestion to include a picture of Cumberland Rum Butter revealed the students' attention both to the referential and appellative functions of their translation (as well as to the need for concision), as implicitly indicated in their translation brief. The students also demonstrated their awareness that different translation strategies should be used when translating culture-bound terms and treating place names, depending on the context, on how well-known a specific culturebound term might be in the target-text readers' cultural context in general and, more specifically, on the target-text readers' prior knowledge. This suggests a high level of flexibility, which is concerned with the «ability to adapt language learnt to new situations», in line with the CEFR C1 relevant descriptor (2020: 138; see also 2018: 139). Flexibility was demonstrated by students not only in the way in which they solved the cultural translation problems posed by their source text, but also the pragmatic ones. For instance, addressing their readers by $t u$ and discussing the appropriateness of the informal expression and bel sole (translating the original sunny skies), revealed Student Group 3's effort to establish a direct relationship with their readers and to attract their attention, as recommended in the translation brief. This shows the ability to «make a positive impact on an intended audience by effectively varying style», as indicated in the CEFR C1-band «flexibility» descriptor (2020: 138; see also 2018: 139).

Moreover, Student Group 3's comment on one of their peers' choice of persona amata (loved one), used instead of a male noun, opened a discussion on the current debate challenging the use of male forms as neutral, which revealed the students' sociolinguistic competence. This was confirmed by the discussion of the use of idiomatic expressions, such as soddisfare gli occhi e il palato, thus revealing the ability to «use language flexibly and effectively for social purposes», as indicated in the CEFR C1-band of the sociolinguistic competence descriptor (2020: 137; see also 2018: 138).

\section{CONCLUDING REMARKS}

As shown above, guiding students during their translation process by encouraging them to undertake the five stages recommended by Malmkjær through well-thoughtthrough activities following Nord's top-down procedure led students to reflect on their Italian target-text implied readers, the desired function and the context in which this might be received. This encouraged them to share a number of reflections on the translation problems faced, to propose different translation solutions and, significantly, to justify them. This in turn helped students to focus on the purpose of their communication and to make accurate language choices by considering the socio-cultural context of their prospective translation, such as their implied Italian readers' expectations and prior knowledge as well as the client's requirements, as shown by the students' observations when justifying their translation choices and by their efforts to be concise, clear and persuasive. These results therefore confirm the hypothesis that teaching translation as a purposeful activity by simulating real-life translation 
commissions can help students to mediate a text effectively by using language purposefully, as shown by the pluricultural, pragmatic and sociolinguistic competences discussed above. In light of this, we can conclude that pedagogical translation is a valuable tool in the language classroom and that drawing on translation studies teaching models can help to teach translation as a purposeful activity, thus enhancing learners' communicative ability in real life, as recommended by the CEFR.

These results would be further validated by evaluating functionalist translation studies models through a quantitative analysis of students' in-class discussions. Examining students' translation assignments, thus discussing translation as a product, would also be beneficial. This would allow us to test observations that properly-briefed assignments help students to feel confident enough to diverge from the syntactical structures and the vocabulary used in the source text, thus avoiding interferences from their L1. A survey-based study would also be useful as it would enable us to evaluate the benefits of integrating a translation studies approach in the language classroom from a student perspective. These perspectives would further validate the results of this empirical study which reveals the benefits of blending language pedagogy and translation studies approaches.

\section{REFERENCES}

Brusasco P., Caimotto M. C., Martelli A. (2011), "Insegnare a tradurre. Esperienze di didattica all'Università di Torino e una modesta proposta", in Tradurre: Pratiche teorie strumenti: https:// rivistatradurre.it/modesta-propostaunito/.

Carreres Á. (2006), "Strange Bedfellows: Translation and Language Teaching. The Teaching of Translation into L2 in Modern Languages Degrees: Uses and Limitations", in Sixth Symposium on Translation, Terminology and Interpretation in Cuba and Canada, December 2006, La Havana: Canadian Translators, Terminologists and Interpreters Council, pp. 1-21:

http://www.cttic.org/ACTI/2006/papers/Carreres.pdf.

Carreres Á., Noriega-Sánchez M. (2011), "Translation in Language Teaching: Insights from Professional Translator Training", in The Language Learning Journal, 39, pp. 281-297.

Carreres Á. (2014), "Translation as a Means and as an End: Reassessing the Divide", in The Interpreter and Translator Trainer, 8, 1, pp. 123-135.

Carreres Á., Noriega-Sánchez M., Calduch C. (2018), Mundos en palabras, Routledge, London.

Carreres Á., Noriega-Sánchez M., Pintado Gutiérrez L. (2021), "Introduction: Translation and Plurilingual Approaches to Language Teaching and Learning", in Translation and Translanguaging in Multilingual Contexts, 7, 1, pp. 1-16.

Cohen A., Brooks-Carson A. (2001), "Research on Direct vs. Translated Writing: Students' Strategies and their Results", in The Modern Language Journal, 85, 2, pp. 169-188.

Coleman J. A. (1986), "Requiem for the Prose?", in Modern Languages in Scotland, 29, pp. 98-105.

Council of Europe (2001), Common European Framework of Reference for Languages: Learning, Teaching, Assessment, Strasbourg, Council of Europe Publishing: https://rm.coe.int/1680459f97. 
(C) Italiano LinguaDue 2. 2021. M. C. Seccia, Teaching Translation from English into Italian as a Purposeful Activity in the Language Classroom: An Empirical Study

Council of Europe (2018), Common European Framework of Reference for Languages: Companion Volume with New Descriptors, Council of Europe Publishing, Strasbourg: https://rm.coe.int/cefr-companion-volume-with-new-descriptors2018/1680787989.

Council of Europe (2020), Common European Framework of Reference for Languages: Learning, Teaching, Assessment. Companion Volume, Council of Europe Publishing, Strasbourg: https://rm.coe.int/common-european-framework-of-reference-for-languageslearning-teaching/16809ea0d4. Trad. it. Trad it. a cura di Barsi M., Lugarini E., Quadro comune europeo di riferimento per le lingue: apprendimento, insegnamento, valutazione. Volume complementare, in Italiano LinguaDue, 12, 2, 2020: https:/ / riviste.unimi.it/index.php/promoitals/article/view/15120.

Cragie S., Higgins I., Hervey S., Gambarotta P. (2000/2016), Thinking Italian Translation: A Course in Translation Method: Italian to English, $2^{\text {nd }}$ edition, Routledge, LondonNew York.

Delisle J. (1980), L'analyse du discours comme méthode de traduction. Initiation à la traduction française de textes pragmatiques anglais. Théorie et pratique, Presses de l'Université d'Ottawa, Ottawa.

Enriquez Raido V., Austermuhl F., Sanchez Torron M. (2020), "Computer-Assisted L2 Learning and Translation (CAL2T)", in Laviosa S., Gonzales-Davies, M. (eds.), The Routledge Handbook of Translation and Education, Routledge, London-New York, pp. 278-299.

Gonzalez-Davies M. (2004), Multiple Voices in the Translation Classroom: Activities, Tasks and Projects, John Benjamins, Amsterdam.

Gonzalez-Davies M. (2014), "Towards a Plurilingual Development Paradigm: From Spontaneous to Informed Use of Translation in Additional Language Learning", in The Interpreter and Translator Trainer, 8, 1, pp. 8-31.

Gonzalez-Davies M. (2018), "The Integrated Plurilingual Approach (IPA): A Case Study in Barcelona," in CEFR-QualiMatrix: A Quality Assurance Matrix for CEFR Use: Examples of Promising Practices. European Centre for Modern Languages of the Council of Europe:

https://www.ecml.at/ECML-Programme/Programme2016-

2019/QualityassuranceandimplementationoftheCEFR/PromisingPractice/tabid/ 3091/language/en-GB/Default.aspx?\&q=Barcelona.

Haywood L., Thompson M., Sándor H. (1995/2009), Thinking Spanish Translation: A Course in Translation Method: Spanish to English, Routledge, London-New York.

Hervey S., Cragie S., Higgins I., Gambarotta P. (2000/2005), Thinking Italian Translation Tutor's Handbook, $2^{\text {nd }}$ edition, Routledge, London-New York.

Källvist M. (1998), "How Different Are the Results of Translation Tasks? A Study of Lexical Errors", in Malmkjær K. (ed.), Translation and Language Teaching, St. Jerome, Manchester, pp. 77-87.

Källvist M. (2004), "The Effects of Translation Exercises versus Gap-Exercises on the Learning of Difficult L2 Structures: Preliminary Results of an Empirical Study", in Malmkjær K. (ed.), Translation in Undergraduate Degree Programmes, John Benjamins, Amsterdam, pp. 163-184.

Källvist M. (2008), "L1-L2 Translation versus no Translation: A Longitudinal Study of Focus-on-formS within a Meaning-focused Curriculum", in Ortega L., Byrnes H. (eds.), The Longitudinal Study of Advanced L2 Capacities, Routledge, London, pp. 182202.

Keith H., Mason I. (eds.) (1987), Translation in the Modern Languages Degree, Centre for Information on Language Teaching and Research, London. 
(C) Italiano LinguaDue 2. 2021. M. C. Seccia, Teaching Translation from English into Italian as a Purposeful Activity in the Language Classroom: An Empirical Study

Kobayashi H., Rinnert C. (1992), "Effects of First Language on Second Language Writing: Translation versus Direct Composition", in Language Learning, 42, 2, pp. 183-209.

Laufer B., Girsai N. (2008), "Form-focused Instruction in Second Language Vocabulary Learning: A Case for Contrastive Analysis and Translation", in Applied Linguistics, 29, 4, pp. 694-716.

Lavault E. (1985), Les fonctions de la traduction dans l'enseignement des langues, Paris, Didier Erudition.

Laviosa S. (2014), Translation and Language Education. Pedagogical Approaches Explained, Routledge, London.

Laviosa S., Gonzalez-Davies, M. (eds.) (2020), The Routledge Handbook of Translation and Education, Routledge, London-New York.

Leonardi V. (2010), The Role of Pedagogical Translation in Second Language Acquisition. From Theory to Practice, Peter Lang, Frankfurt.

Malmkjær K. (1998), "Introduction: Translation and Language Teaching", in Malmkjær K. (ed.), Translation and Language Teaching: Language Teaching and Translation, St Jerome, Manchester, pp. 1-11.

Marsh M. (1987), "The Value of L1>L2 Translation on Undergraduate Courses in Modern Languages", in Keith H., Mason I. (eds.), Translation in the Modern Languages Degree: Proceedings of a Conference Held at Heriot-Watt University, Edinburgh, 5 7 Jan. 1986, CILT, Edinburgh, pp. 22-30.

Nord B. (2015), "Analisi dei problemi traduttivi in un modello didattico applicato. I quattro problemi traduttivi secondo Christiane Nord", in Tradurre: pratiche teorie strumenti: https://rivistatradurre.it/2015/11/analisi-dei-problemi-traduttivi-in-unmodello-didattico-applicato/.

Nord C. (1988/2005), Text Analysis in Translation: Theory, Methodology, and Didactic Application of a Model for Translation-Oriented Text Analysis, $2^{\text {nd }}$ edition, Rodopi, Amsterdam.

Nord C. (1994), "Translation as a Process of Linguistic and Cultural Adaptation", in Dollerup C., Loddegaard A. (eds.), Teaching Translation and Interpreting 2, John Benjamins, Amsterdam, pp. 59-68.

Nord C. (1997a/2018), Translating as a Purposeful Activity: Functionalist Approaches Explained, $2^{\text {nd }}$ edition, Routledge, London.

Nord C. (1997b), “A Functional Typology of Translations", in Trosborg A. (ed.), Text Typology and Translation, John Benjamins, Amsterdam, pp. 43-66.

North B., Piccardo E. (2016), Developing Illustrative Descriptors of Aspects of Mediation for the Common European Framework of Reference (CEFR). Research Project, Council of Europe, Strasbourg.

Panzarella G., Wall G. (2016), "Focus sulla sensibilità linguistica: la traduzione collaborativa nella classe di lingua", in Italiano LinguaDue, 8, 2, pp. 328-337: https://riviste.unimi.it/index.php/promoitals/article/view/8190.

Panzarella G., Sinibaldi C. (2018), "Translation in the Language Classroom: Multilingualism, Diversity, Collaboration", in EuroAmerican Journal of Applied Linguistics and Languages, 5, 2, pp. 62-75.

Pintado Gutiérrez L. (2012), "The Use of Translation towards Foreign Language Autonomous Learning”, in Alderete-Diez P., Incalcaterra McLoughlin L., Ni Dhonnchadha L. (eds.), Translation, Technology and Autonomy in Language Teaching and Learning, Peter Lang, Oxford, pp. 175-195.

Pintado Gutiérrez L. (2018), "Translation in Language Teaching, Pedagogical Translation, and Code-Switching: Restructuring the Boundaries", in The Language Learning Journal, 49, 2, pp. 1-21. 
(C) Italiano LinguaDue 2. 2021. M. C. Seccia, Teaching Translation from English into Italian as a Purposeful Activity in the Language Classroom: An Empirical Study

Pintado Gutiérrez L. (2019), "Mapping Translation in Foreign Language Teaching: Demystifying the Construct", in Koletnik M., Froeliger N. (eds.), Translating and Language Teaching. Continuing the Dialogue, Cambridge Scholars Publisher, Cambridge, pp. 23-38.

Pym A., Malmkjær K., Gutiérrez-Colón Plana M. (2013), Translation and Language Learning, European Commission, Luxembourg.

Pym A. (2018), "Where Translation Studies Lost the Plot: Relations with Language Teaching", in Translation and Translanguaging in Multilingual Contexts, 4, 2, pp. 204222.

Schjoldager A. (2004), "Are L2 Learners more Prone to Err when They Translate", in Malmkjær K. (ed.), Translation in Undergraduate Degree Programmes, John Benjamins, Amsterdam, pp. 127-150.

Seel O. I. (2015), "Intercultural Pragmatics and Text Typology: An Integrated Approach to Translation Teaching", in Cui Y., Zhao W. (eds.), Handbook of Research on Teaching Methods in Language Translation and Interpretation, IGI Global, Hershey, pp. 199-219.

Sewell P., Higgins I. (eds.) (1996), Teaching Translation in Universities: Present and Future Perspectives, CILT, London.

Torresi I. (2014), Translating Promotional and Advertising Texts, Routledge, London.

Uzawa K. (1996), 'Second Language Learners' Processes of L1 Writing, L2 Writing, and Translation from L1 to L2", in Journal of Second Language Writing, 5, pp. 271-294.

Vaezi S., Mirzaei M. (2007), "The Effect of Using Translation from L1 to L2 as a Teaching Technique on the Improvement of EFL Learners' Linguistic Accuracy Focus on Form", in Humanising Language Teaching, 9, 5, pp. 79-121.

Vienne J. (1994), “Toward a Pedagogy of 'Translation in Situation”', in Perspectives: Studies in Translatology, 2, 1, pp. 51-59.

Wetherby J. (1998), "Teaching Translation into L2: A TT-Oriented Approach", in Malmkjær K. (ed.), Translation and Language Teaching: Language Teaching and Translation, St Jerome, Manchester, pp. 21-38.

Whyatt B. (2009), "Translating as a Way of Improving Language Control in the Mind of the L2 Learner: Assets, Requirements and Challenges of Translation Tasks", in Witte A., Harden, T., Ramos de Oliveira Harden A. (eds), Translation in Second Language Learning and Teaching, Peter Lang, Bern, pp. 181-202.

\section{Sitografia}

Alessandro Marras' documentary episode Galles: Regno Unito: https://www.youtube.com/watch?v=1PRzGMYkDiM.

Avanti Destinations: https://www.avantidestinations.com/home.

Friuli Venezia Giulia Official Tourist Office: https://www.turismofvg.it/.

TranslateMedia: https://www.translatemedia.com/.

VisitScotland: https://www.visitscotland.com/. 